\title{
New Perspective of Art Education Reform in Normal University under Elementary Art Education Reform
}

\author{
Chenying Li
}

Zhang Daqian School of Fine Arts, Neijiang Normal University, 641000

\begin{abstract}
Key words: Art education reform; Teaching methods;Teaching means; Community service
\end{abstract}
\begin{abstract}
Art education in normal university must pay attention to elementary art education reform to improve education and teaching quality and cultivate art teachers with international horizon, strong competitiveness, creativity, critical thinking abilities and individualized development. Through elementary art education reform and professional studies of art education in normal university, the author has proposed the following viewpoints: adjusting curriculum provision, adding new courses suitable to elementary art education reform; conducting reforms on teaching methods and means; valuing cultivation of research-oriented teachers; strengthening guidance and management of social practice courses and improving their social adaptation abilities; paying attention to the cultivation of students' humanistic spirit and aesthetic accomplishment; valuing the uniqueness of art teaching and leaning theory and exerting its unique functions; strengthening the awareness of lifelong learning.
\end{abstract}

\section{Introduction}

In the torrents of international elementary education reform, Chinese elementary educational reform has launched comprehensively. In 2001, Chinese elementary art courses were conducted like a raging fire, and certain achievements were made in various fields. In 2011, official art course standards were implemented and issued, in which the characteristics, ideas, objectives, teaching content, teaching advices and implementation suggestions were made clear and the vision, humanity, practicalness and joy of art courses were highlighted again and the unique role and irreplaceable importance of elementary education were represented.

The main task of art education in normal university is to train excellent art teachers in middle school. Faced with the rapidly changing elementary art education, art education in normal university must get rid of the closed inherent training mode and reform in multiple aspects in order to improve teaching and education quality and cultivate art teachers with international horizon, strong competitiveness, creativity, critical thinking abilities and individualized development. Through researches on elementary art education reform and art education in normal university, the author has proposed the following viewpoints.

\section{Adjusting curriculum provision, adding new courses suitable to elementary art education reform}

There is severe disjoints between the curriculum provision of art education in normal university and elementary art education, and courses such as Calligraphy, Seal Cutting, Sculpture, 
Photography · Camera Shooting, Computer Painting and Computer Design, Art Curriculum Standards required by art education in middle and primary school need to be added to adapt to elementary art education and teaching. The significance of different courses is different. Calligraphy has unique Chinese characteristics, and it is abstract art with lines as modeling and it has strong emotional features; Seal Cutting pays more attention to seal character on the basis of Calligraphy; seal cutting has multiple aesthetic characteristics, and its characteristics in calligraphy, sculpture, painting and graphicalization all manifest its unique art aesthetics; in Sculpture courses, differences of Chinese and Western sculpture art will be compared and creative teaching of sculpture art methods will be introduced, the application of comprehensive materials will be tried and the innovative representation of sculpture art will be conducted, which can strengthen students' manipulative ability and creative ability; Photography · Camera Shooting has become an inseparable part in daily life; it extends our vision, and its recording and representational role can never be compared by painting; the course should start from the specialty of photography, the operations and compositions of cameras, etc.; Computer Painting and Computer Design are necessary skills in digital times; utilizing operational methods of modern media, taking advantage of art language, forms and modern art creative points for the expression of ideas and emotions; Art Curriculum Standards aims to strengthen students' understanding, grasping and utilization of elementary art courses, and it is of great importance in strengthening students' art education. The provision of these courses can improve the capability and quality of students majoring in art education in normal university and adapt to elementary art education effectively.

\section{Conducting reforms on teaching methods and means in normal university}

Art education in normal university is still injection-type and passive. Students' learning efficiency is low, and their creative thinking and critical thinking are repressed; their learning interest and innovative ability are both insufficient. Therefore, it is especially important to study teaching methods of different types of courses. Different teaching methods have their different functions and it is difficult to choose and control teaching methods. Most of the art teachers in normal university are postgraduates from art universities, so their grasp of education and teaching methods is limited and it is necessary to conduct training on their teaching methods and means; meanwhile, they should be guided in teaching methods and means. Only by training them can the goal of art education in normal university be realized. Art courses have vision, creativity and practicalness. Aiming at its characteristics, appropriate art education and teaching methods are chosen appropriately, and laying solid basis for students' cognition ability, practical ability, aesthetic ability and innovative ability with diversified teaching methods; meanwhile, paying attention to appropriate application of diversified teaching methods. It is not the more, the better for the theory of multiple teaching. Only when teachers grasp multiple conditions and choose the most appropriate teaching methods that adapt to students' physiological and psychological characteristics can the teaching methods and means be the best. Бабанский once said, "in case teaching becomes a kaleidoscope that changes activity forms continuously, students' attention on the essence and content of the textbook are dispersed." [1] In the reform of art education in normal university, it is 
critical to pay attention to the appropriate choice and reasonable utilization of the theory of multiple teaching in order to reach optimization and guarantee the realization of teaching objectives.

\section{Valuing the learning and guidance of community art service courses}

Community service is a specific area for every student's comprehensive practical activities; meanwhile, it is a special project for students to know the society and integrate into life. Community construction is a new work, the inevitable requirement for economic and social development in Chinese cities and an important approach for urban modernization construction. It relies on social forces, takes advantage of social resources, strengthens community functions, resolves community problems and promotes community political, economic cultural and environmental harmony and healthy development, and it can improve the life standard and quality of community members. Art education in normal university relies on the society to a great extent and it breaks away from the community as well as the foundation of our survival. University has the responsibility and obligation to provide good services for the construction and development of communities. In art education in normal university, the learning and guidance of community art service courses should be paid attention to, students can recognize the experience, sociality, service and autonomy of community service, and "the happiness and satisfaction of serving for others, developing one's own sympathy and care and the quality of respecting others, and stimulating the incentive of learning" through investigation, research and guidance of comprehensive practical activity courses. [2] The knowledge and skills students have learned can be activated, their practical wisdom can be developed and their comprehensive qualities can be strengthened.

\section{Valuing the cultivation of research-oriented teachers}

Exerting the guidance role of research-oriented teachers in universities, implementing in the way of theme research learning, strengthening research study content and guidance. For example: aiming at differences of Chinese and Western painting thoughts, the different expressive means of Chinese and Western paintings and emotional reveling ways in paintings, guiding students to find problems and confirm project. Cultivating students' problem awareness, understand the development link of the project, utilize development strategies and specific implementation ways, summarize, communicate and reflect in time and improve students' research abilities and innovative awareness by establishing problem situation, thereby providing research-oriented teachers for future elementary art education.

\section{Strengthening the guidance and management of students' social practice courses and improving their social adaptation abilities}

Social practice is of great importance in deepening university students' understanding of the major, confirming their suitable career, making preparations for job market and strengthening employment 
competitive advantages. Art schools in normal university should strengthen education internship, professional internship and education practice, which are the main content of practical teaching; meanwhile, they should also treat practical teaching as an important constituent of class teaching and establish stable and diversified educational practice base, which contributes to consolidating students' art professional theoretical knowledge, strengthening teaching achievements, broadening applicability and innovation so that university students can experience achievement of human civilization contained in all courses, carry forward national spirit, represent scientific spirit, reveal the essential rules of things during the process of practical teaching; their innovative spirit and practical abilities can be cultivated. Implementing social investigations profoundly. Organizing university students to carry out researches and investigations on major problems in economic society, proposing suggestions and advices and forming investigation results. Universities should strengthen the management and guidance of the topic-selection, approaches and process of university students' social investigations, set social investigation courses or lectures, help university students to understand social phenomena, grasp scientific research methods, improve their ability of analyzing problems and solving problems and grasp the essence and rules of things.

\section{Paying attention to the cultivation of students' humanistic spirit and aesthetic accomplishment}

Humanistic spirit is humans' pursuit for their own completion and the realization of ideals, the pursuit goals and spiritual pursuit for their own values as well as humans' persistent pursuit for ideal world, ideal characteristics and ultimate pursuit that transcends realities. Art is a humanistic discipline that contains rich humanity and it represents humanistic spirit. In art works, humans' values are uplifted, and humans' significance of existence, human dignity, values, moralities and cultural traditions are confirmed sufficiently. In reforms of art courses, art works are combined with cultural situations, so different orientation of human values are understood; humans' maintenance of their own dignity and their pursuit for justice and freedom can broaden humanistic vision and improve their humanistic qualities and aesthetic qualities. Humanistic spirits are represented in various aspects, such as Vincent van Gogh's The Starry Night, Night Coffee Shop and Irises and Xu Beihong's Galloper and TianHengWuBaiShi, Zhang Daqian's AiHenhu, etc., human being's unremitting pursuit for the true, the good and the beautiful are represented in all of them and it is human being's continuous surpassing of humanistic spirit. In art education reform, teachers should also pay attention to students' real life and strengthen the joys of experiencing life; pay attention to the cultivation of aesthetic experiences and improve their aesthetic interests and aesthetic qualities.

\section{Valuing the uniqueness of art teaching and leaning theory and exerting its unique functions}

The fundamental objective of art education in normal university is to cultivate high-quality art teachers for elementary art education reform. Art teaching theory courses are the core courses of art teacher education. It has practicalness, theoretical property and comprehensiveness and it is also an important course for normal university students majoring in art to transform from theoretical 
knowledge to practical teaching abilities as well as a required course for art teacher education. Students can grasp knowledge of middle school art teaching by learning, form a certain educational philosophy and teaching skills and be equipped with preliminary art education and teaching research abilities; it contributes to forming new art teaching philosophy that can adapt to social reforms and talent demands in the background of new curriculum reform so that students can grasp and utilize various practical abilities in middle school art teaching and reach the society's urgent demands for high-quality art teachers. Various normal universities should strengthen the management of the course and researches on corresponding teaching problems and pay attention to its practicalness, innovation and applicability. Art teaching theory teachers and administrative staff should all join in the reform of teaching theory curriculum actively. They should upgrade teaching philosophy, innovate teaching means, complete teaching methods, locate teaching objective accurately, be detailed in teaching process, show care in teaching evaluation so that the course of art teaching theory can exert its unique role in the cultivation of art teachers.

\section{Strengthening the awareness of lifelong learning}

A human is developing in all his life, and he is in the social environment of dynamic development. The development of information technology has accelerated social transitions, and dynamic requirement of integral qualities is a giant challenge to future teachers. Art education in normal university must pay attention the cultivation of students' lifelong learning awareness, and learning is bound to run through a person's whole life.

\section{Conclusion}

Art education in normal university must pay attention to the process of elementary art education reform. Closed, rigid and single teaching is bound to get students away from modernization process, while the transformation of teaching philosophy and the combination of philosophy and theory will get art university normal students to a new stage, and students' creativity, competitiveness and individual education will be improved substantially and become excellent art education reserved talents.

\section{References:}

[1] Written by Бабанский. Translated by Wu Wenkan. The Optimization of Teaching Educational Process [M] . Beijing: Science and Education Press, 2001.

[2] Compiled by Sichuan Province Ministry of Education Sichuan Normal University Elementary Education Course Research Center, Regular High School Curriculum Reform Comprehensive Practical Activity Implementation and Case [M] . Sichuan Normal University press, 2010.08 